\title{
"Almohada" catatónica
}

\section{Catatonic "pillow"}

\section{Diego A. Rondón-Pinto ${ }^{1,2, a}$, Lizardo Cruzado ${ }^{1,2, b}$.}

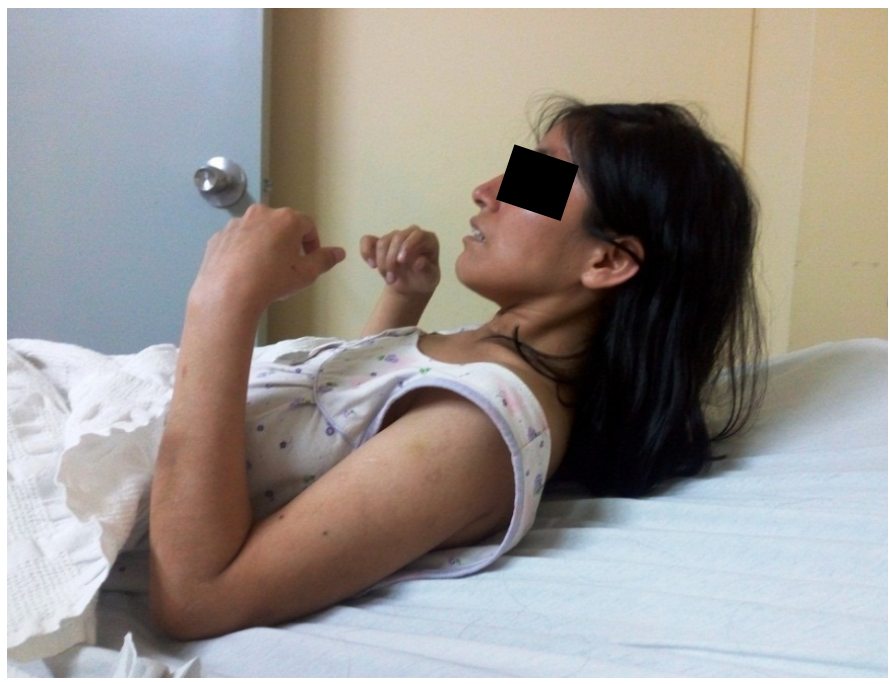

La catatonía, descrita por Kahlbaum en 1874, es el último síndrome misterioso de la medicina: abarca fenómenos en los extremos de la motilidad (desde el estupor a la agitación más desaforada) y peculiaridades incomprensibles de la conducta psicomotora con incremento del tono muscular. Por ejemplo, la postura que se muestra en la imagen, fue mantenida casi 10 minutos por la paciente luego de retirada su almohada. El síndrome catatónico se debe mayormente a patologías médicas y neurológicas y trastornos psiquiátricos del ánimo, no es exclusivo de la esquizofrenia, como se asumía antes. El empleo de antipsicóticos como el haloperidol empeora gravemente el cuadro, el tratamiento de elección es con benzodiacepinas o, si fallasen, la terapia electroconvulsiva, suele lograr una respuesta rápida. La encefalitis por anticuerpos contra el receptor NMDA de glutamato representa una causa emergente de catatonía. Ante este síndrome, extraño y soslayado pero no infrecuente, cabe recordar el adagio: "el médico encuentra lo que busca, y busca lo que conoce."

Catatonia was first reported by Kahlbaum in 1874 and is the last mysterious syndrome in medicine; it involves alterations in the motility (from stupor to extreme agitation) and incomprehensible peculiar alterations in the psychomotor behavior with increase in the muscle tonicity. For instance, the posture shown in the image was maintained by the patient for almost 10 minutes after removing the pillow. The catatonic syndrome follows medical, neurological and psychiatric moody pathologies, it is not exclusive of schizophrenia as was assumed before. Haloperidol severely worsens the clinical manifestations, benzodiazepines or electroconvulsive therapy if the former fails are the therapeutic measures of choice. Encephalitis caused by antibodies to the NDMA receptor is an emerging cause of catatonia. When confronted with this rare syndrome it is wise to remember the adage that says: "the physician finds what he is looking for and searches for what he knows"

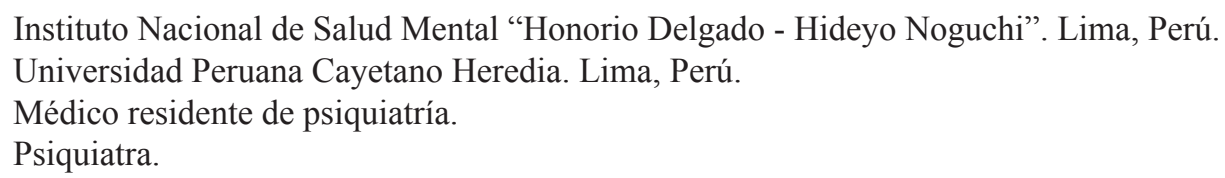

